\title{
Identification and representation of water pathways from production areas to urban catchment outlets: a case study in France
}

\author{
F. Seveno ${ }^{1}$, F. Rodriguez ${ }^{1}, \mathrm{~K}$. de Bondt ${ }^{2} \&$ C. Joannis ${ }^{1}$ \\ ${ }^{1}$ IFSTTAR: Institut Français des Sciences des Technologies \\ des Transports et des Réseaux, France \\ ${ }^{2}$ ESSC-VUB: Earth System Sciences, \\ Vrije Universiteit Brussel, Belgium
}

\begin{abstract}
Hydrographic networks in urban areas combine several sources and water pathways, including buried channels and, more recently, source control practices. Moreover, pervious areas may be either directly or indirectly connected to drainage facilities and pipe water seepage. All these pathways have significant operational consequences since they challenge design principles, sizing guidelines and operating rules for both collection and treatment facilities, which might even undermine the efforts to improve the quality of receiving waters.

The project proposed herein aims to generate a detailed description of the water pathways on an urban catchment in order to assess the impact of urban planning strategies and provide guidelines for sewer system evaluation and rehabilitation.

The work presented in this paper has taken place within the Pin Sec catchment (Nantes, France); it consists of collecting and analyzing groundwater, wastewater and rainwater in the catchment and then applying the isotopic and chemical results to trace the mixing that occurs in the pipes. Results reveal that isotopic tracing is indeed relevant on this catchment. The isotopic signatures of drinking water and groundwater vary sufficiently during spring, up to $1.5 \%$ for $\delta^{18} \mathrm{O}$ and up to $12 \%$ for $\delta^{2} \mathrm{H}$ in May. The ratios of defective connections and water seepage may be deduced from this output. Chemicals also support the findings of the isotopic tracing results.
\end{abstract}

Keywords: water stable isotope, major element chemistry, urban hydrology, tracing technique. 


\section{Introduction}

Throughout the world, urban populations are currently growing at a faster pace. City expansions require improved management of the urban environment. The resultant urban sprawl involves the creation of impervious areas (e.g. roads, buildings) and water supply and sewer systems, all of which greatly affect the water cycle: impervious areas serve to reduce water infiltration, increase evaporation and runoff, and shorten catchment response time (Fletcher et al. [1]). A city's aquifer may be viewed as a complex environment with multiple entry sources (Lerner [2]). Impervious areas are connected to urban infrastructure and channelized systems (gutters, sewer pipes), which constitute known water pathways. Pervious areas, on the other hand, are not controlled, and the exchanges between ground and sewer system might be very complex in terms of connections (directly vs. indirectly connected) and processes (infiltration, inflow, exfiltration, etc.). Moreover, recent urban water planning guidelines commonly imply revised rainwater management strategies, which call for rainwater source control and a strong emphasis on rainwater re-infiltration. All these uncontrolled pathways have significant operational consequences since they challenge existing design principles (separate collection), sizing procedures and operating rules for collection and treatment facilities, in addition to potentially jeopardizing efforts to improve receiving water quality. The aim of the present study, therefore, is to obtain a detailed description of the water pathways within an urban area, from rainwater and drinking water inputs through to the separate sewer and water table outputs. These pathways can merge and generate mixed water contributions in the sewer output: direct runoff, leakage from drinking water pipes, groundwater drainage infiltration, etc. In order to distinguish these contributions, our work relies on two interconnected approaches that include experimental study and modeling. The experimental study involves isotopic tracing $\left(\delta \mathrm{O}^{18}, \delta \mathrm{H}^{2}\right)$ and chemical parameters (major metallic elements and anions); it focuses on sewer system infiltration (via wastewater pipes and rainwater sewer pipes) and the exchanges occurring between buried pipes during dry weather periods. Wet periods will be treated in further works, in order to better identify the water pathways during rain events. This paper details the research methodology and initial results of our experimental work.

\section{Methodology}

\subsection{Study area}

The Pin Sec district is located northeast of the city of Nantes (France); this catchment encompasses roughly 31 ha and 2,505 residents and moreover is home to the ONEVU regional observatory of urban environments. ONEVU's objectives comprise studying the interactions taking place between the city and its environment through observations of water, pollutants and energy fluxes. The study area is composed of a separate sewer system (Figure 1). The rainwater sewer system supplies the Gohards River downstream, to the east of the 
catchment. All pipes are made of concrete. This catchment is equipped with a dense network of measurement devices, including rainfall and water flow rate gauges at the outlets of both rainwater and wastewater sewer systems; these devices are capable of measuring the flow rate at 2-min intervals for the rainwater system and at 5-min intervals for the wastewater system. Water table variations are deduced from a set of 11 piezometers using a 20-min time step; turbulent heat fluxes, including evapotranspiration, are estimated thanks to a micrometeorology mast (Le Delliou [3]). Hydrological data, including piezometric levels and water flow rates are available since 2007. The variation of the base flow throughout the year during dry weather periods is between 0.5 $10 \mathrm{~m}^{3} / \mathrm{h}$ for the rainwater system and $0.5-22 \mathrm{~m}^{3} / \mathrm{h}$ for the wastewater system (Jankowfsky [4]).

The mean annual precipitation is around $800 \mathrm{~mm}$. On this catchment, previous work has been carried out to investigate rainwater pollution (Percot [5]), urban groundwater modeling (Le Delliou et al. [6]) and the water balance (Jankowfsky [4]).
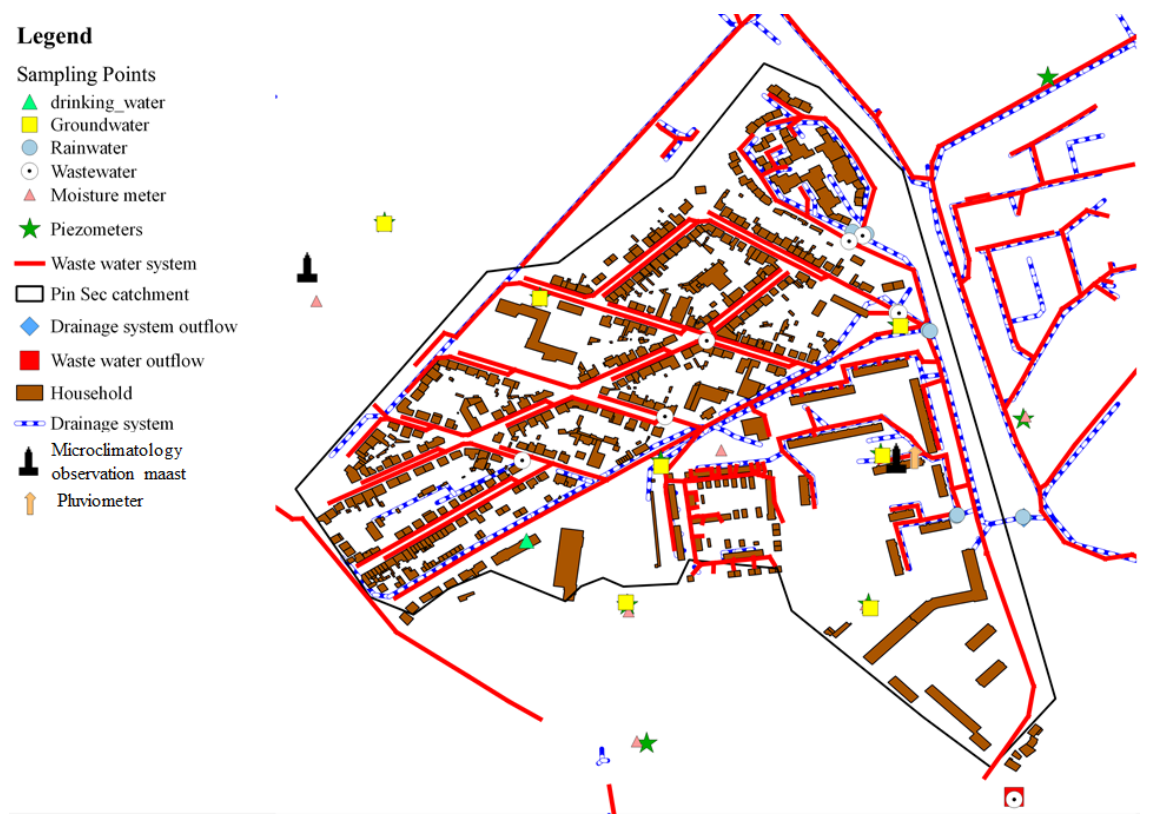

Figure 1: Pin Sec catchment.

\subsection{Tracing technique}

\subsubsection{Water mixing}

The aim of this study was to qualify and quantify the contributions of the various potential water sources in the sewers and rainwater system. We used two types of tracer to quantify the amount of water mixing: the isotopic (water stable isotope) and geochemical (major, anion, metal). These tracers were analyzed for 
all types of water capable of entering into the wastewater and rainwater pipes (groundwater, wastewater, tap water, rainwater, etc.) (Table 1). Initial results (see below) have already revealed some combinations of the various tracers, so as to quantify and localize the water that mixes into the sewers and rainwater pipes during dry weather periods.

Table 1: Component differentiation.

\begin{tabular}{|c|c|c|c|}
\hline & & & Origin \\
\hline \multirow{12}{*}{ Outlets } & \multirow{6}{*}{ Waste water pipe (WW) } & \multirow{3}{*}{ Dry weather } & Waste water generation \\
\hline & & & Groundwater seepage $^{2}$ \\
\hline & & & Drinking water exfiltration ${ }^{b}$ \\
\hline & & \multirow{3}{*}{ Wet weather } & Dry weather component \\
\hline & & & Pervious area production \\
\hline & & & Wrong connexion $\mathrm{RW}>\mathrm{WW}^{\mathrm{C}}$ \\
\hline & \multirow{6}{*}{ Rain water pipe (RW) } & \multirow{3}{*}{ Dry weather } & Groundwater seepage ${ }^{2}$ \\
\hline & & & Wrong connexion WW $>\mathrm{RW}^{\circ}$ \\
\hline & & & Drinking water exfiltration $^{b}$ \\
\hline & & \multirow{3}{*}{ Wet weather } & Dry weather component \\
\hline & & & impervious area production \\
\hline & & & Pervious area production ${ }^{d}$ \\
\hline
\end{tabular}

$\mathrm{a}[7] ; \mathrm{b}[8] ; \mathrm{c}[9] ; \mathrm{d}[1]$.

The inputs of these various components can be described by the following equations (Kracht [10]):

$$
\begin{aligned}
Q_{t} C_{T}^{A} & =\sum_{i=1}^{i} C_{i}^{A} Q_{i} \\
Q t & =\sum_{i=1}^{i} Q i
\end{aligned}
$$

where $Q_{t}$ is the total outflow, $C_{T}^{A}$ the concentration of element A at the outlet, $C_{i}^{A}$ the concentration of element A within the various inputs $i$, and $Q_{i}$ the outflow of the various inputs $i$. The outflow measurement is not available on each branch of the sewer system, hence Equations (1) and (2) become:

$$
\begin{gathered}
C_{T}^{A}=\sum_{i=1}^{i} X_{i}^{A} C_{i} \\
1=\sum_{i=1}^{i} X_{i}
\end{gathered}
$$

where $X i$ represent the water fractions stemming from the various inputs $i$. 


\subsubsection{Isotopic and geochemical tracer}

Stable isotopes were used as tracers to quantify groundwater inflow into the sewer system (De Bénnédittis and Bertrand-Krajewski [7], Kracht [10]). This method is available during dry weather periods only when the isotopic signature differential between the distinct waters entering the sewer is sufficiently significant. This situation may arise when drinking water is pumped from a water source affected by different climatic conditions than those for the water recharging the local aquifer. Nantes' municipal drinking water originates from the Loire River; the river water that ultimately arrives in Nantes is thus a mix of runoff and groundwater stemming from the Loire catchment, which extends further to the south and center of France. Consequently, the isotopic signature of the Loire River will also vary seasonally. The differences in isotopic signature may be sufficient for a given period and then inadequate for the rest of the year.

We focused the chemical analyses on 18 elements $(\mathrm{Ba}, \mathrm{Ca}, \mathrm{Fe}, \mathrm{K}, \mathrm{Mg}, \mathrm{Mn}$, $\mathrm{Na}, \mathrm{Sr}, \mathrm{Zn}, \mathrm{Cl}, \mathrm{Si}, \mathrm{Ni}, \mathrm{P}, \mathrm{B}, \mathrm{Cu}, \mathrm{Br}^{-}$and $\left.\mathrm{Cl}^{-}\right)$. Some of them were described in the literature from studies mainly performed on non-urban catchments: $\mathrm{Si}$ and $\mathrm{Mg}$ (Wels et al. [11] $\mathrm{Na}, \mathrm{K}, \mathrm{Cl}, \mathrm{Ca}, \mathrm{Ba}$ and $\mathrm{Sr}$ (Ben Othman et al. [12]). Only the work of Panno et al. [13], which studied the ratio of the $\mathrm{Br}$ and $\mathrm{Cl}$, studied the urban environment. The other elements (B, Cu, Fe, Mn, Ni, P, Zn) were chosen because they are often typical of runoff impact in urban areas (Lamprea and Ruban [14]).

\subsubsection{Experimental procedure}

The aim of these campaigns was to determine the chemical and isotopic signatures of the groundwater, wastewater, rainwater system water and mixed compositions between these individual sources, to evaluate the possible benefit of this two methods. Four test campaigns were carried out on the catchment in April, May, August and November 2013, with varying numbers and locations of samples. The work conducted by Le Delliou [3] determined the pipes of sewer system in which groundwater infiltration might occur during both low and high water table periods. These pipes have been sampled to characterize the chemical and isotopic signatures of the mix. On the contrary, those sewer segments assumed to be less influenced by the aquifer are sampled to characterize the signatures of just the wastewater on its own.

The experimental procedure consists of dry weather sampling (campaigns from April 2013 to April 2014) scheduled every 2 months after at least 3 days without rainfall. During a single campaign 9 samples were combined from various locations in the wastewater system, along with 6 rainwater system samples. Moreover, 7 piezometers were sampled from across the catchment (Fig. 1) in order to characterize possible spatial and temporal variations in the chemical and isotopic signatures of the aquifer. The samples in the sewer system were sampled in the morning (between $9 \mathrm{~h}-12 \mathrm{~h}$ ) or in the afternoon (13h-16h). The piezometers were sampled during the afternoon (13h-16h30). The isotopic results from the campaign of May are presented. The chemical results from the campaigns of May, August and November are presented. 


\subsubsection{Methodology of sampling}

During a single campaign and for each sample, 1 liter of water is sampled manually for the isotopic and chemical analysis. Concerning the groundwater, the piezometers were purged once in the morning. The sampling began in the afternoon. For the isotopic analysis, $30 \mathrm{ml}$ are re-sampled in a glass bottle were we add one drop of $\mathrm{HgCl}_{2}$ to prevent any contamination from the bacterial activities. The time between the sampling and the isotopic analyses could be long (few months). To prevent any contamination of our samples, they are stored at temperatures below $6^{\circ} \mathrm{C}$ in the obscurity. These isotopic analyses $\left(\delta \mathrm{O}_{18}, \delta \mathrm{H}_{2}\right)$ were conducted by means of Cavity-Ring Down Spectroscopy (Picarro L-2130) at the Vrije Universiteit Brussel (VUB) institution and offered an analytical precision of ${ }_{-}^{+} 0.05 \%$ o for $\delta^{18} \mathrm{O}$ and ${ }_{-}^{+} 0,3 \%$ for $\delta^{2} \mathrm{H}$ (repeatability verified for all 84 samples analyzed). The following results are expressed in delta notation, in accordance with the VSMOW international standard.

The conductivity of the sample is measured on-site. The COD (chemical oxygen demand) and suspended matter were measured within a 24-hour period following sampling, while the major anion, cation and metal element concentrations were recorded using an Ion Chromatograph (ICS-2100) and Atomic Emission Spectrometry by Inductively Coupled Plasma (ICP-OES 720) on the dissolved and particulate phases. The samples used to analyze metal and major elements were acidified with a $1 \%$ nitric acid concentrate. The silica samples were not acidified in order to prevent silicate precipitation. The dissolved phase was filtered with a Millipore filter $(0.45 \mu \mathrm{m})$.

\section{Results and discussion}

\subsection{Isotopic results}

Samples from a campaign carried out in May 2013 were analyzed (see Table 2 and Fig. 2); the corresponding results have been presented by plotting the $\delta \mathrm{O}_{18}$ vs. $\delta \mathrm{H}_{2}$ isotopic values.

The isotopic signature between the piezometers and wastewater differs by at least $0.6 \%$ (per mil) for $\delta \mathrm{O}_{18}$ and $6.2 \%$ for $\delta \mathrm{H}_{2}$, with both these values exceeding the analytical uncertainty threshold $\left({ }^{ \pm} 0.05 \% 0\right.$ for $\delta^{18} \mathrm{O}$ and ${ }_{-}^{ \pm} 0,3 \%$ for $\delta^{2} \mathrm{H}$, repeatability verified for all 84 samples analyzed). However, the endmembers of the mixing-line must be carefully chosen since they represent the major uncertainty on the derived mixing proportion. The stable isotopic composition of strict wastewater is significantly different from that of drinking water from $0.2 \%$ for $\delta \mathrm{O}_{18}$ (Table 2). According to Schilperoot et al. [15], this slight signature shift may be caused by specific household tap water uses (e.g. hot water for dishwashing and laundry by hand). The wastewater samples that differ from pure wastewater (Fig. 2) are most likely a mix of wastewater and groundwater, which remains above the sewer level all year round (Le Delliou [3]). The Nancy Street sample is the most heavily influenced by groundwater infiltration; in applying the concentration mixing equations (Eqs (1)-(4)), the 
Table 2: $\quad$ Summary of the isotopic results (in per mil (\%o)) for drinking water, groundwater, wastewater along with the wastewater value in the Nancy Street's pipe, and the rain water along with the Guiotton Street.

\begin{tabular}{|l|l|r|r|r|}
\hline & $\delta^{18} \mathrm{O}$ & $\begin{array}{l}\text { Standard } \\
\text { deviation }\end{array}$ & $\delta^{2} \mathrm{H}$ & $\begin{array}{l}\text { Standard } \\
\text { deviation }\end{array}$ \\
\hline Drinking water & $-7,17$ & & -47 & \\
\hline $\begin{array}{l}\text { Waste water building's rejection } \\
\text { (mean) }\end{array}$ & $-6,94$ & 0,09 & -45 & 0,62 \\
\hline $\begin{array}{l}\text { Waste water sewer pipe with } \\
\text { groundwater seeping (Nancy's street) }\end{array}$ & $-6,37$ & & -41 & \\
\hline Groundwater (mean) & $-5,43$ & 0,19 & $-32,6$ & 1,49 \\
\hline Rain water system not impact (mean) & $-5,43$ & 0,06 & -33 & 0,42 \\
\hline $\begin{array}{l}\text { Rain water sewer pipe impacted } \\
\text { (wrong connection and/or drinking } \\
\text { water re-infiltration) (quiotton street) }\end{array}$ & $-6,12$ & & & \\
\hline
\end{tabular}

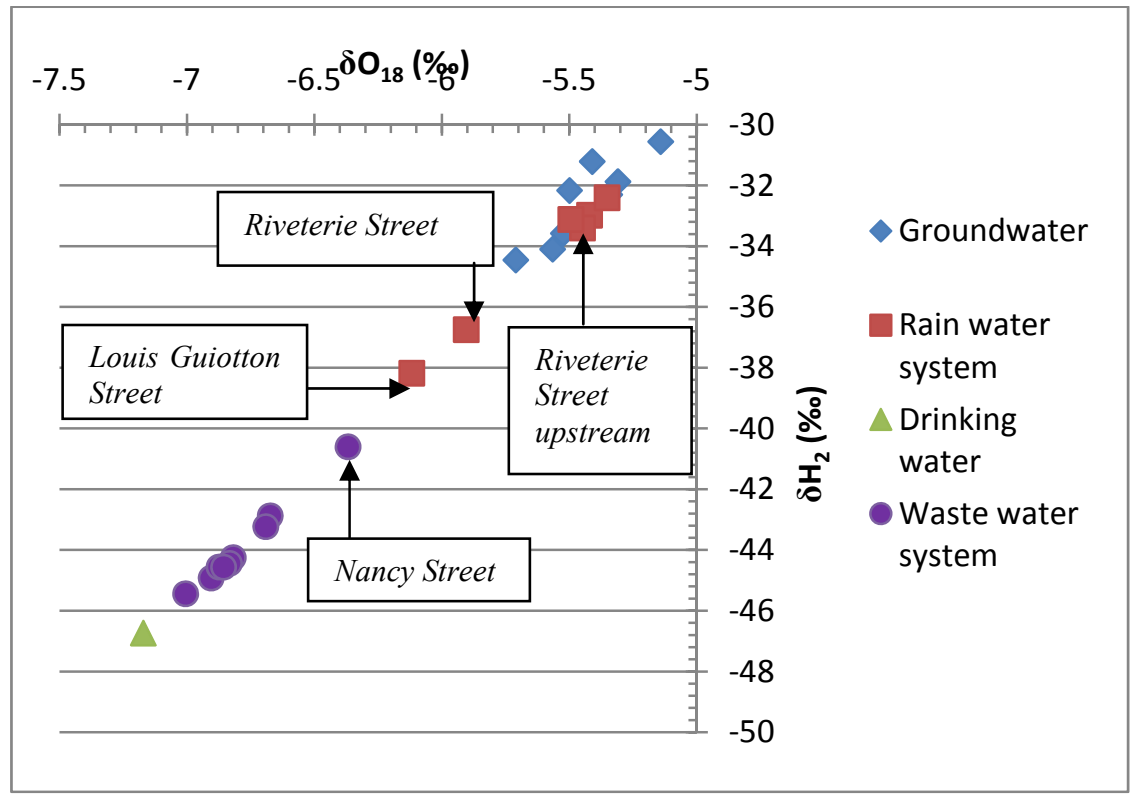

Figure 2: Isotopic result (May 2013).

fraction of infiltrated groundwater can be estimated for this sample at: $42 \%+3 \%$ with ${ }^{18} \mathrm{O}$ and $37 \%+1 \%$ with ${ }^{2} \mathrm{H}$.

Water sampled from the rainwater system reveals that 4 samples with isotopic signatures (from -5.44 to $-5.35 \%$ o for $\delta \mathrm{O}_{18}$ and from -32.4 to $-33.4 \%$ or $\delta \mathrm{H}_{2}$ ) very close to the groundwater signature (from $-5.7 \%$ to $-5.1 \%$ for $\delta \mathrm{O}_{18}$ and from $-34.4 \%$ o to $-30.5 \%$ o for $\delta \mathrm{H}_{2}$ ) (Table 2). For the other two samples, the stable isotopic composition of the rainwater system differs from groundwater by $0.2 \%$ 
for $\delta \mathrm{O}_{18}$ and by $2 \%$ for $\delta \mathrm{H}_{2}$. The Riveterie Street sample constitutes a mix of the Louis Guiotton Street and upstream Riveterie Street samples. As for the Louis Guiotton Street sample, the isotopic signature might be influenced by either a defective connection or drinking water exfiltration, which may eventually reinfiltrate into the pipes. The estimated fraction of such infiltrated water is: $42 \% \_3 \%$ with ${ }^{18} \mathrm{O}$ and $39 \% \_4 \%$ with ${ }^{2} \mathrm{H}$.

\subsection{Chemical results}

These analyses focused on the variation in barium (Fig. 3, Table 3), phosphorus (Fig. 4, Table 4) and kalium (i.e. potassium) (Fig. 5, Table 5) concentrations.

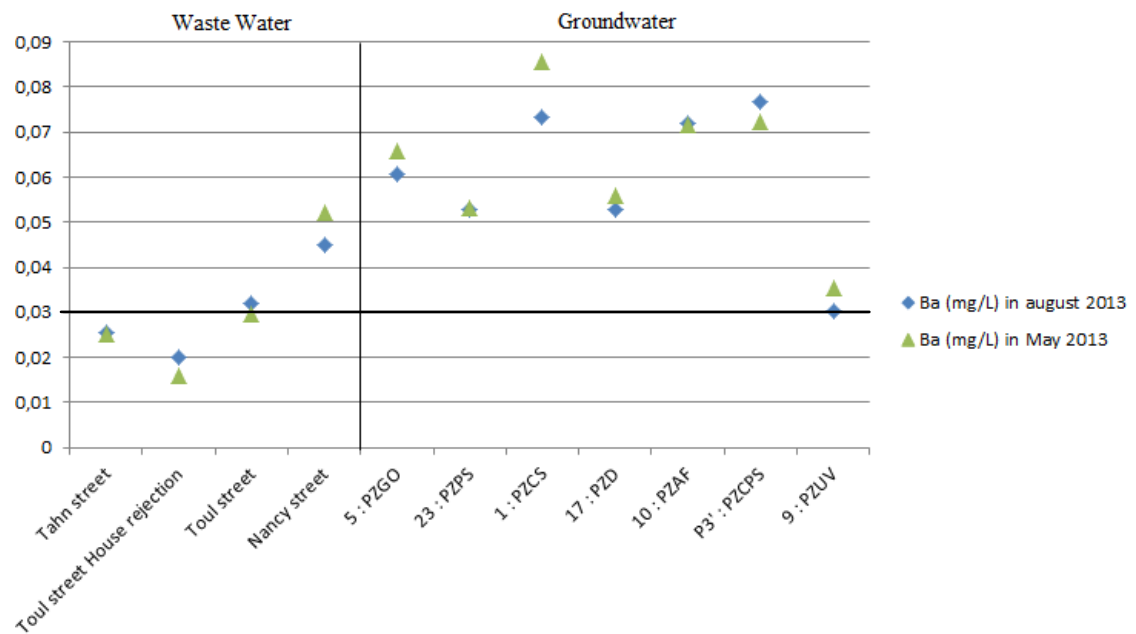

Figure 3: Barium concentration difference (in $\mathrm{mg} / \mathrm{L}$ ) in May and August 2013 between wastewater and the groundwater. The sampling points are the piezometer $(\mathrm{PZ})$ and manhole in the waste water system on different streets. The horizontal line represents the maximal acceptable value for Barium in waste water $(0.03 \mathrm{mg} / \mathrm{L})$.

These wastewater results (Tables 2-4) present wide spatial and temporal variability in concentration for the major elements. Such variability might be related to the impact of human behavior and practices within the various neighborhoods of this catchment.

Barium concentrations (Fig. 3, Table 3) in the wastewater are used to determine aquifer infiltration into sewer water. Barium concentrations are relatively stable over time in both the groundwater and wastewater system yet are variable in space. During the two months of this study, groundwater concentration exceeded wastewater system concentration. The Nancy Street value is always the parameter that maximizes wastewater system concentration. 
Table 3: $\quad$ Summary of the result of the Ba concentration results (in $\mathrm{mg} / \mathrm{L}$ ) for groundwater, wastewater along with the wastewater value in the Nancy Street's pipe.

\begin{tabular}{c|l|r|r|}
\hline \multirow{2}{*}{ Month } & & $\begin{array}{l}\text { Waste water system } \\
\text { (Ba in } \mathrm{mg} / \mathrm{L})\end{array}$ & $\begin{array}{l}\text { groudwater } \\
\text { (Ba in } \mathrm{mg} / \mathrm{L})\end{array}$ \\
\hline \multirow{3}{*}{ May } & Nancy street & 0,05 & \\
\cline { 2 - 4 } & mean & 0,03 & 0,06 \\
\cline { 2 - 4 } & standart deviation & 0,01 & 0,02 \\
\hline \multirow{3}{*}{ August } & Nancy street & 0,047 & \\
\cline { 2 - 4 } & mean & 0,03 & 0,06 \\
\cline { 2 - 4 } & standart deviation & 0,01 & 0,02 \\
\hline
\end{tabular}

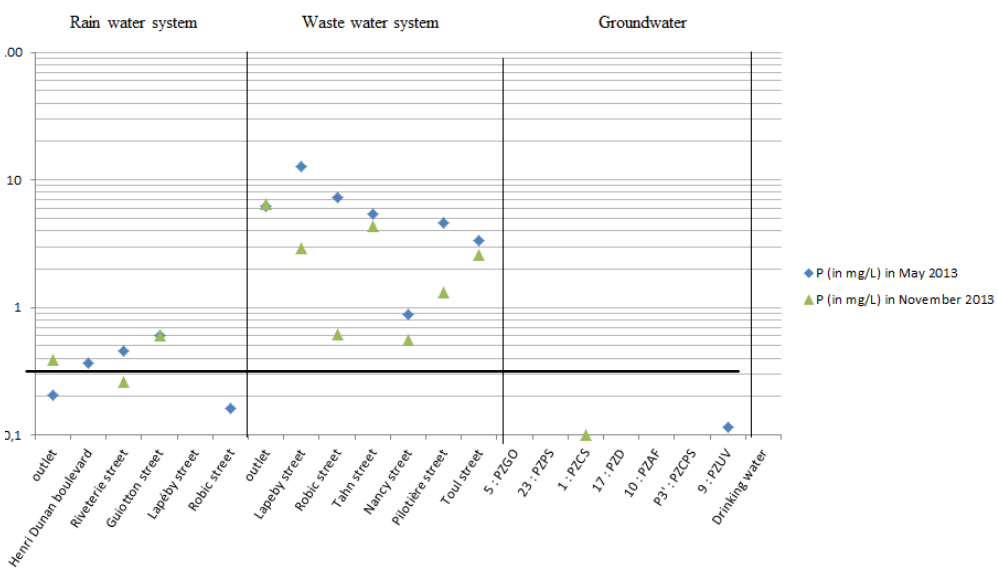

Figure 4: $\quad$ Phosphorous concentration (in $\mathrm{mg} / \mathrm{L}$ on a logarithmic scale) in May and in November 2013 on the rainwater system, wastewater system, and groundwater. The horizontal line represents the maximal acceptable value for Phosphor in rain water system (0.3 mg/L).

Table 4: $\quad$ Summary of the Phosphorous concentration results (in $\mathrm{mg} / \mathrm{L}$ ) for the groundwater, the wastewater, the rainwater system; along with the rainwater for Guiotton Street.

\begin{tabular}{|c|l|r|l|l|}
\hline \multirow{3}{*}{ Month } & & $\begin{array}{l}\text { rain water system } \\
(\mathrm{P} \text { in mg } / \mathrm{L})\end{array}$ & $\begin{array}{l}\text { Waste water system } \\
(\mathrm{P} \text { in } \mathrm{mg} / \mathrm{L})\end{array}$ & $\begin{array}{l}\text { groudwater } \\
(\mathrm{P} \text { in } \mathrm{mg} / \mathrm{L})\end{array}$ \\
\hline \multirow{3}{*}{ May } & Guiotton street & 0,6 & & \\
\cline { 2 - 6 } & mean & 0,3 & 5,7 & $<0,1$ \\
\cline { 2 - 6 } & standart deviation & 0,14 & 3,13 & \\
\hline \multirow{3}{*}{ November } & Guiotton street & 0,6 & 2,69 & $<0,1$ \\
\cline { 2 - 6 } & mean & 0,42 & 2,17 & \\
\cline { 2 - 6 } & standart deviation & 0,17 & & \\
\end{tabular}




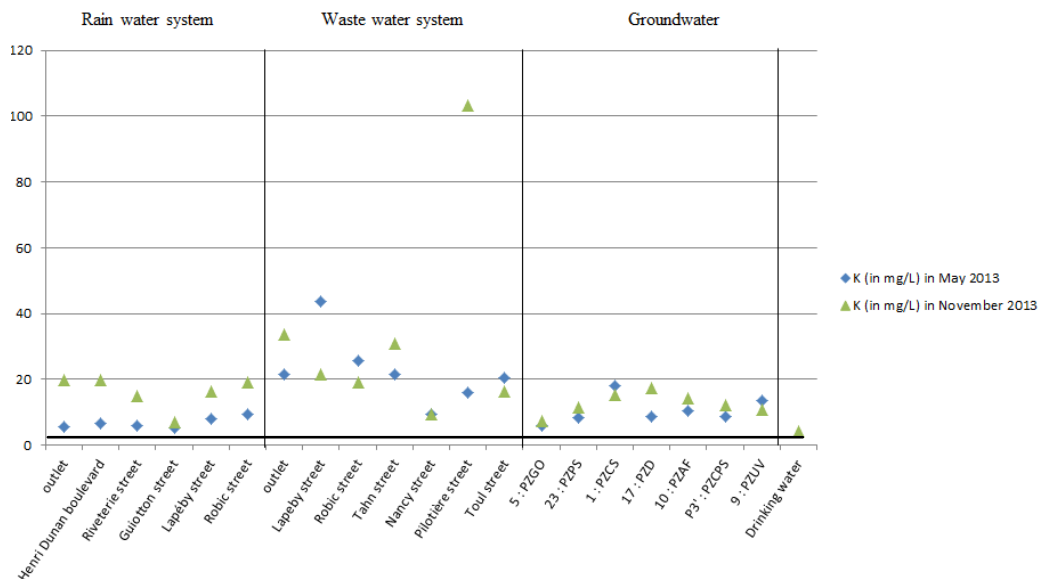

Figure 5: Kalium (i.e. Potassium) concentration (in $\mathrm{mg} / \mathrm{L}$ ) in April and in May 2013 for the rainwater system, wastewater system and groundwater. The horizontal line represents the minimal acceptable value for Kalium (i.e. Potassium) in rain water system $(6 \mathrm{mg} / \mathrm{L})$.

Table 5: Summary of the Kalium concentration results (in $\mathrm{mg} / \mathrm{L}$ ) for the groundwater, the waste water, the rain water system and the value of the rain water for Guiotton Street.

\begin{tabular}{|c|l|r|r|r|}
\hline \multirow{3}{*}{ Month } & & $\begin{array}{l}\text { rain water system } \\
(\mathrm{K} \text { in mg/L })\end{array}$ & $\begin{array}{l}\text { Waste water system } \\
(\mathrm{K} \text { in } \mathrm{mg} / \mathrm{L})\end{array}$ & $\begin{array}{l}\text { groudwater } \\
(\mathrm{K} \text { in mg/L })\end{array}$ \\
\hline \multirow{3}{*}{ May } & Guiotton street & 5,2 & & \\
\cline { 2 - 6 } & mean & 6,58 & 32,7 & 10 \\
\cline { 2 - 6 } & standart deviation & 1,64 & 15,5 & 4,2 \\
\hline \multirow{3}{*}{ November } & Guiotton street & 6,9 & & 12,69 \\
\cline { 2 - 6 } & mean & 16,13 & 22,69 & 3,33 \\
\cline { 2 - 6 } & standart deviation & 4,94 & 10,59 & \\
\hline
\end{tabular}

Barium is not really used in households (Host et al. [16]). Hence; the variability associated with uses inside a household does not explain the higher concentration observed at the point influenced by the aquifer. By inputting the concentration mixing equations with $\mathrm{Ba}$, the fraction of infiltrated water may be estimated at: $75 \%+10 \%$ in May and $53 \%+4 \%$ in August.

The concentrations of phosphorous (Fig. 4, Table 4) and kalium (Fig. 5, Table 5) allow determining sources other than groundwater in the pipe labeled Guiotton rainwater system. Phosphorous concentration in the groundwater is less than or equal to the ICP-OES quantification limit $(0.1 \mathrm{mg} / \mathrm{L})$ for the two months. Groundwater values remain stable over time and space. The rainwater system displays higher variability. The Guiotton rainwater system pipe always indicates 
a higher phosphorous concentration. The only phosphorous source on this catchment is wastewater generation. As seen in the previous section, this pipe has an isotopic signature different from the aquifer (Guiotton rainwater system point), which may be due to a mistaken wastewater input into the rainwater system. The fraction calculation implies $10 \%+2$ and $20 \% \pm 2$ of wastewater input into this pipe in May and November respectively.

The kalium concentration is higher in groundwater and wastewater for both time periods, which suggests a contribution from another component flowing into this pipe; this other component might very well be drinking water reinfiltration.

\section{Summary and conclusion}

The combination of isotopic and geochemical tracing provides valuable information regarding the various water sources found in sewers. This tracing procedure aims to draw the possible connections of pervious and impervious areas to sewers and determine their associated fluxes. The calculation of water infiltrating into the wastewater sewer system shows wide variability between the isotopic and geochemical data. The isotopic method indicates an infiltration of $42 \%{ }_{-}^{+} 3 \%$ with the $\delta^{18} \mathrm{O}$ and $37_{-}^{+} 1 \%$ with $\delta^{2} \mathrm{H}$ in May, whereas the barium concentration value yields $75_{-}^{+} 10 \%$ of infiltrating water in May. Even though barium is rarely used in households, the value in sewer pipes ranges between 0.25 and $0.35 \mathrm{mg} / \mathrm{L}$. In groundwater, these variations lie between 0.35 and $0.95 \mathrm{mg} / \mathrm{L}$. The calculation of the portion of infiltrating water has been conducted using the arithmetic mean of the sewer pipe and groundwater. This method appears to overestimate the infiltrating water fraction. Calculation accuracy could be increased by acquiring a better description of the system (i.e. by selecting the nearest piezometer) to better characterize the water that infiltrates into the sewer system. The analysis of a full hydrological year will serve to complete this study by assessing the seasonal variations in groundwater infiltration into sewers.

The second phase of this experimental study will consist of a wet weather campaign, in order to estimate the various source contributions during rainfall events, especially the contribution of rain. Results will then be used to model the application via the URBS (Urban Runoff Branching Structure) framework (Rodriguez et al. [17]). This model is able to simulate the various contributions of pervious and impervious areas to an urban catchment; moreover, its capacity to differentiate between these contributions will be evaluated thanks to previous tracing results.

\section{References}

[1] Fletcher T.D., Andrieu H., Hamel. P., "Understanding, management and modelling of urban hydrology and its consequences for receiving waters: A state of the art", Advances in water resources, vol. 51, pp. 261-279, 2013. 
[2] Lerner D.N., "Identifying and quantifying urban recharge: a review", Hydrogeology journal, vol. 10, pp. 143-152, 2002.

[3] Le Delliou A., "Rôle des intéractions entre les réseaux d'assainissement et les eaux souterraines dans le fonctionnement hydrologique d'un bassin versant en milieu urbanisé. Approche expérimentale et modélisations.", 2009.

[4] Jankowfsky S., "Urban water balance and impact of water sensitive urban design on the catchment water balance", 2012.

[5] Percot S., "Contribution des retombées atmosphériques aux flux de polluants issus d'un petit bassin versant urbain- cas du Pin Sec à Nantes", 2012.

[6] Le Delliou A.L., Rodriguez F., Andrieu H., "Modélisation intégrée des flux d'eau dans la ville - Impacts des réseaux d'assainissement sur les écoulements souterrains", La houille-Blanche, vol. 5, pp. 152-158, 2009.

[7] De Bénédittis J., Bertrand-Krajewski J.L., "Measurement of infiltration rates in urban sewer system: use of oxygen isotopes", Water and environmental management series, 2004.

[8] De Silva D., Burns. L.S., Eiswirth M., "Joints in water supply and sewer pipelines: an australian perspective", in Proc. from Wagga Wagga, 2001.

[9] Hoes O.A.C., Schilperoort R.P.S., Luxemburg W.M.J., Clemens F.H.L.R., Van de Giesen N., "Locating illicit connections in storm water sewers using fiber-optic distributed temperature sensing", Water Research, vol. 43, no. 20, pp. 5187-5197, 2009.

[10] Kracht. O., "Tracer-based hydrograph separation methods for sewer systems", 2007.

[11] Wels C., Cornett R.J., Lazerte B.D., "Hydrograph separation: a comparison of geochemical and isotopic tracers", Journal of hydrology, vol. 122, pp. 253-274, 1991.

[12] Ben Othman D., Luck J-M., Tournoud M-G., "Geochemistry and water dynamics: application to short time-scale flood phenomena in a small Mediterranean catchment I Alkalis, Alkali-earths and $\mathrm{Sr}$ isotopes", Chemical Geology, vol. 140, pp. 9-28, 1996.

[13] Panno S.V., Hackley K.C., Hwang H.H., Greenberg S.E., Krapac I.G., Landsberger S.O., Kelly D.J., "Characterisation and identification of NaCl Sources in Groundwater”, Groundwater, vol. 44, pp. 176-187, 2006.

[14] Lamprea K., Ruban V., "Pollutant concentrations and fluxes in both stormwater and wastewater at the outlet of two urban watersheds in Nantes (France)" Urban water journal, vol. 8, pp. 219-231,2011

[15] Schilperoort R.P.S., Meijer H.A.J. Flamink C.M.L., Clemens F.H.L.R., "Changes isotope ratio during domestic wastewater production", in Book of Proceedings, 2006.

[16] Host S., Krakowiak D., Elluin M., "Evaluation et gestion de l'exposition au baryum," 2005.

[17] Rodriguez F., Morena F., Andrieu H., "Development of a distributed hydrological model based on urban databanks-- production processes of URBS.”, Water Science and Technologies, vol. 52, pp. 241-248, 2005. 